Mary Rhoads, Health Sciences Center Library 3404, University of Arizona, 1501 N. Campbell Avenue, Tucson, AZ 85724.

26-28 - North Carolina: "Stand Up for Libraries," biennial conference of the North Carolina Li- brary Association, Benton Convention Center and Hyatt Hotel, Winston-Salem. Contact: Leland M. Park, Library of Davidson College, Davidson, NC 28036; (704) 892-2000, ext. 331.

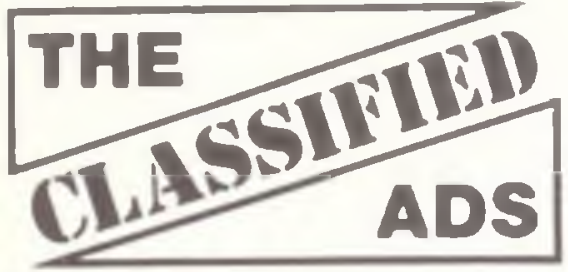

Deadlines: Orders lor regular classified advertisements must reach the ACFL office on or before the second of the month preced. ing pubication of the issue (e.g. September 2 for the October issue) Late $\mid \mathrm{ob}$ listings will be accepted on a space-available basis after the second of the month

Fales: Classified advertisements are $\$ 4.00$ per line for ACRL members $\$ 5.00$ for others Late ob notices are $\$ 10.00$ per line tor members, $\$ 1200$ for others. Organizations submitting ads will be charged according to their membership stalus

Telephone: All telephone orders should be confirmed by a written order mailed to ACRI headquarters as soon as possible Orders should be accomparied by a typewritten copy of the ad to be used in prootreading. An additional $\$ 10$ will be charged tor ads taken over the phone (except ate job notices or display ads)

Guidelines: For acs which list an applicalion deadline, that date must be no sooner than the last day of the month in which the nolice appears (e.g. October 31 for the October issue). All job announcements should include a salary ligure. Job announcements will be edited to exclude discriminatory relerences Applicants should be aware that the terms faculty rank and status vary in meaning among inslitulions.

JOBLINE: Call (312) 9446795 for late-breaking job ads for academic and research library positions. A pre-recorded summary of positions listed with the service is revised weekly; each Friday a new lape includes all ads received by 1:00 p.m the previous day Each lisling submitted will be carried on the recording for two weeks. The charge for each two.week listing is $\$ 30$ for ACRL members and \$35 for non-members.

Fas1 Job LIs1/ng Service: A special newsletter for those actively seeking positions. This service lists job postings received at ACRL headquarters lour weeks before they appear in C\&RL News. as wel as ads which, because of narrow deadlines, will not appear in C\&RL News The cost of a six-month subscription is $\$ 10$ for ACRL mem. bers and $\$ 15$ for non-members

Contact: Classified Advertising Dep't. ACRL. American Library Association, 50 E Huron St. Chicago IL 60611 (312) 944-6780

\section{FOR SALE}

ELSEVIER ANTIQUARIAN DEPARTMENT. Periodicals and rare bocks on Llfe- and Earth Sciences. Over 1 million volumes on stock. Catalogues available on demand. Please write to: Lippijr straat 4, $1055 \mathrm{KJ}$ Amsterdam. The Netherlands

\section{POSITION DESIRED}

AL A - A CCAEDITED MLS. One year protessional experience in $\mathrm{Re}$ ference/Collection Development Knowledge of computer and foreign ianguages Desires similar position. Will relocate. Omar Khalidi 2462 Dalton. Wichita, KS 67210

\section{POSITIONS OPEN}

ASSISTANT CATALOGER. ALA-MLS Some catalogino exper ence required Knowledge of LC classification and OCLC (or other retwork) Coursework in business and economics helpful. We are in the process of planning for an integrated online system One year appointment $\$ 15.000$ + depending upon qualiticalions and experience. Send resume and three letters of reference to: Virgil F Mass man. Executive Director James Jerome Kill Reference Library, St Paul MN 5510 ? EOE.

ASSISTANT ENGINEERING LIGRARIAN. A permanent position available July 1, 1983 Under direction of the Engineering Librariar duties include reference and information services database searching cf BAS. Lockheed, and OCLC: bibliographic instruction collection development liaison with faculty; original cataloging of monographs. staff supervision; and special projects utilizing the En gineering Library's microcomputer system Required: master's de gree in library science from an ALA-accredited library school, or its equ valent: ev dence of research orientation and ability 10 meel uriversity requirements for promotion and tenure: commitment to serving the research needs of clientele Preferred: subject background or library experience in engineering or related science. Desirable: experience or proficiency in reference service, cataloging, biblio graphic instruction, collection development, and online database searching. Librarians have laculty rank Assistant Prolessor rank lor applicant with desired experience and qualifications, inc uding evdence of ability to meel general university requirements for promo tion and tenure (research, publication, university/community/professional service) in addit on to performing specific library assignment Salary $\$ 14.500$ upward, depending on qualifications and scholarly credentials Send complele resume with names and addresses of five references to. Allen G. Dries, Libraries Personnel Manager, Un versity of Illinos at Urbana-Champaign, $127 \mathrm{~L}$ brary, $1408 \mathrm{~W}$. Gre gory Drive. Urbana. I L 61801 phone (217) 333-8169. For maximum consideration, applications and nominations should be received no ater than July 31,1983 The University of Illinois is an affirmative acton, equal opportunity employer.

ASSISTANT HEAD, CHEMISTRY LIBRARIAN. Afiliate, Assis tant or Associate Librarlan Provides relerence service, including on ne interactive searching and library instruction: assists in collec tion development; directly supervises the library operations, includ ing supervision and training of one tull-tıme support staff, and over sees all lechrical services operations. Master's degree from an ALA-accredited library school: minimum of one year post-MLS brary experience preferred: supervisory experience; experience with computer-assisted reference services; demonstrated ability to relate effectively to faculty, students, and staff Effectiveness in plar ning and organizing work llow Some academic background in sc. ence and/or experience in a science-oriented library Ability to commuricate effectively both orally and in writing. Reading knowledge of German is desirable ability to meet the responsibilities and require ments of a tenure-track appointment Salary dependent on qualificafions and experience Salary minımum. Affiliate \$14,500: Assistant. \$15.800. Associale, $\$ 18.500$ Send letters of application to. Anne Rimmer. Personnel Officer, Indiana University Libraries Blcomington. IN 47405: (812) 335-3403 Closing date for applications no earler than June 15, 1983 . Indiana University is an equal opportunity, affirmative action employer

ASSISTANT LIBRAFIAN. Southern Arkansas University has a va cancy for an assistant librarian effective immediately. Applicants should hold the MIS degree and have three to four years experience as a reterence librarian in a four -year college or un versity library A more complete job description is available Salary is commensurate with training and experience Southern Arkansas University is an equat opportunity, affirmative action employer. Applications will be received until position is filled Interested persons should send lelle of interest and resume to: L A Logan. President for Academic Al tairs, Southern Arkansas Universily, Box :402 Magnolia, AR71753

ASSISTANT PROFESSOR. Search reopened. The University of III nois Gradt ale Sch ool of Library and Inlormation Science is seeking candidales for a full-1me tenure-track position for teaching two or more of the following areas information science cataloging, medical relerence, special li braries, and/or science reference Full-time teaching laad equals two courses per semester plus sharing in stucenl advising and faculty committee work. Earned dociorate in hrary and information science preferred, and library (or information center) and leaching experience desirable. The University of Illinors offers excellent research resources, inc uding six million plus volume 1 brary. computer facilities, manuscript typing, etc. Minimum salary $\$ 20,000$ Summer session and exlersion leachirg with additional pay is possible but not required. Pasition open August 21, January 
1984 starting date possible. Send letter of application, resume, and names of three persons from whom references can be secured, to: Charles H. Davis, Dean, Graduate School of Library and Information Science. University of Illinois, 410 David Kinley Hall, 140? W. Gregory Dr. Urbana, IL 61801; (217) 333-3280. Applications will be accepted until June 27 , or until a sutable candidate has been found. The University of Illinois is an affirmative action, equal opportunity employer

ASSISTANT UNDERGRADUATE LIBRARIAN (MEDIA COORDI NATOR). A permanent position avallable August 1 1983. Under drection of the Assistant Director for Undergraduate Libraries and In structional Services, administers the Library Audio/Media Center, a playback - not production-lacility housed in the Undergraduate Li brary. Assignment includes supervision ol 2 FTE slaft and a studen wage budget of $\$ 13,500$. Participates in and coordinates all origina Media catalcoing: participates in provision of general reference services and bibliographic instruction; assists with UGL book and journal selection in assigned areas of responsibility: and in areas of sub ject responsibility expected to establish faculty liason and develop reference aids. Other duties as assigned, regular night and weekend work expected. Required: master' s degree in library science from an ALA-accredited library school, or Ils equivalent; at east one year pro tessional experience working in a media center or with non-print materials; demonstrated ability io relate effectively with faculty, students and staff; and evidence of ability to meet University requirements for lenure and promotion. Preferred experience in providing reference and/or biblographic instruction in an academic environment De sired: experience with non-print cataloging, particularly in the area of motion pictures and television. Librarians have faculty rank. Appointment at the Assistant Protessor level. Salary \$16,000 upward de pending on qualifications and experience Librarians must meet general university requirements for promotion and tenure (research. publications, and university/community/professional service) in ad dition to performing specific library assignment. Send complete re sume with names and addresses of five references 10 . Allen $\mathrm{G}$. Dries, Library Personnel Manager. Un versity of Illinols Library at Urbana Champaıgn, 127 Library, 1408 W Gregory Drive, Urbana, IL 6180 phone (217) 333-8169. For maximum consideration, applications and nominafions should be received nolater than July 29, 1983. The University of Illinois is an attırmative aclion, equal opportunity em. ployer.

BEHAVIORAL SCIENCES LIBRARIAN AND SCIENCE LIBAAR

IAN, Two 9-month tenUre track, faculty positions at Chapmar Colege, a private liberal arts college in Southern Cailfornia. Responsıbıthes: teaching required library research courses, general reference, and liaison with faculty and students in subject areas including collection development, online bibliographic searching. and catalog ing. Required MLS from ALA accredied school and 2 years aca demic library experience. Prefer second master's and teaching experience. One position requires strong cataloging background Appointment at the Assistant or Associate Prolessor level. Salary range: $\$ 16,400-\$ 31,100$ for 9 months Separate summer contracts usually available. Send letter of application, resume, and three letters of reference by June 30, 1983, to: Janice $\mathrm{H}$. Shawi, Library Director Chapman College Library, $333 \mathrm{~N}$. Glassell St. Orange, CA 92666 Interviews may be held at ALA Conference. Equal opportunity, af firmative action employer

BIOLOGY/NATURAL RESOURCES AND HUMANITIES LIBRARIANS effective August 15, 1983, at the Assistant Librarian. Senior Assistant Librarian or Associate Librarian level as appropr ate depending on qualifications and experience (current salary range $\$ 17,028-\$ 30,672$ ). One of the positions may be combined with the position of Head, Information Services. Closing date July 1,1983 Equal opportunity employer. For more detailed information write: Universily Librarlan, Humbold State University Arcata CA 95521

CATALOGER, entry level new position with responsibility for orig. nal cataloging of monographs and editıng of OCLC copy, using the LC classification schedules and subject headings. Master's degree from ALA-accredited library school. Minimum \$14,500 Academi status. Send letter of application wtih resume and names of three reterences by June 30, 1983, to: Waller M. High. Head, Monographic Cataloging Department, D.H. Hill Library, North Carolina Stale University, PO Box 5007, Raleigh, NC 27650. An equal opportunity, at firmative action employer

CATALOGER, new position. Experienced calaloger with demon straled potential to manage people. Detailed knowledge of MARC formats and the theory underlying the development and use of machine-readable calaloging necessary. Responsibility for orrginal cataloging of monographs and editing of OCLC copy, using the LC classification schedules and subject headings Knowledge of multimedia cataloging will be especially useful. Master's degree from ALA-accredited library school. Minımum \$17,500. Academic status. Send letter of application with resume and names of three references by June 30,1983, to: Walter M High, Head, Monographic Catalog ing Department. D.H. Hill Library. North Carolina State University, PO Box 5007 . Raleigh, NC 27650. An equal opportunity, affirmative aclion employer
CATALOGER, Northwestern Universily Performs original and complex cataloging of monographs, including descriptive and sub ecl cataloging and classification and authority work, using AACR? LCSH. DDC 19 , and the MAFC bibliographic and authority formats Works cataloged may be on any subject, and in a variely of languages. Calaloging and authority work are performed on Northwest. ern's NOT'S (Northwestern Online Total Integrated System) library automat on system, for inclusion in the union online catalog and for warding to the RLIN database. Some authority work may be submitted to the Library of Congress tor inclusion in the Name Authority Cooperative Program (NACO) Qualifications MLS from an ALA-accredited library school, working knowledge of one or more toreign languages, preterably including German or a Romance lan. guage. Experience in library technical services, using an automated system desirable. Position available: open. Salary. $\$ 15,000-\$ 16,000$ depending upon experience. Send application and resume, including names of references to. Lance Query, Personnel Librarian. Northwestern University Library Evanston. IL 60201 . Applications received by July 15, 1983, will be considered. Northwestern University Library is an equal opportunity, affirmative action employer

CATALOGER. Responsible for original cataloging of Latin American malerials. Required: MLS from ALA-accredited school; reading knowledge f Spanish: ability to work with French German and Por luguese workıng knowledge of LC classification and subject headings, AACR2, and OCLC; at least one year of cataloging expenence. Salary: $\$ 16,000$. Two-year term appointment available September 1983. Applicatıon deadline July 1, 1983 Send letter of applicatıon, resume, and names of three references to. Associate Curator for the Pre-Columbian Collection, Dumbarton Oaks, 1703 32nd St NW. Washington, DC 20007

CATALOGING LIBAAAIAN, Responsible for cataloging of all $\|_{-}$ brary materials except music. Formulates cataloging policies and procedures; trains and supervises cataloging staff. Collection development and some reference duties included. Responsible for the creation and maintenance of all authority files Master's degree from ALA accredited library school and at least 3 years experience as a cataloger using an aulomaled system. Second master's degree in a subject field preferred Salary: $\$ 18,800$ + depending upon qualifications and experience. Faculty status and liberal tringe benefits including TIAACREF Send resume and names of 3 references by June 30, 1983, to Deanne Mclinari Affirmative Action Olficer SUNY College at Purchase, Purchase NY 10577.

CURATOR OF RAAE BOOKS AND SPECIAL COLLECTIONS, University of Wisconsin-Madison 12-months academic staff appoinlment Administer a department with 2.5 FTE and 20 hours/week of student assistance, and holdings of 80,000 volumes including malerials of national reputation in hislory of science, little magazines, French pamphlets, Russian underground malerials, and English and American literature. Curator will be encouraced to seek gifts of special collectıons and oulside funding for purchase of rare books. Responsibilities. plan and implement department's public ano technical servces: collection development in history of books and printing. litte magazınes, and rare books reference materials: assist faculty, students, and visitors in use of collections; act as liaison belween department and university teaching units; mount exhibits; work with Friencs of the Library; su pervise the shitt of valuable mate. rials from the general stacks to the rare book vaults: provide lectures and tours for university classes and outside groups; act as liaison to ESTC/NA projecl; represent department, as requested. on university and community committees. Minimum qualifications. ALA. accredited MLS or equivalent demonstrated subject mastery in IIbrarianship, graduate degree in humanities or social sciences; 5 years exper ence in rare books andior special collections preferably In a research library: administrative experience; fore gn language expertise. Salary $\$ 26.000$ minimum. Appontment effect ve September 1,1983 , or as soon thereafter as possible. Application deadline: June 30,1983 . Letter of application, current vita, and names, addresses, and telephone numbers of three reterences to Sandra Pfahler, Assistant Director for Budget and Personnel, 360 Memorial Library. 728 State Street Madison, W 53706. EEOIAA employer.

DEAN OF LEARNING RESOURCES CENTER, Puebto Comm nity College Pueblo Community College is accepting applications for the position of Dean of the Learning Resources Center Appilcants musi possess an ALA-accredited MLS (doctorate of library SCIence desirable). Mınimum experience: candidate shall have been employed full time for one year as a Director of a earning resources center at an institution of higher education. In addition, two years ex. perience as Charperson of a library department is required. The college is seeking an individual with a background in both public and technical services who will provide leadership in working with library staff faculty and administrators: who is knowled geable about the ap plication of computer technology to library processes and who can design and implement projects to increase existıng library re sources. Minimum salary is $\$ 30,000$ for 12 months. The Dean of the Learning Resources Cenler will be responsible to the Vice President for Instructional Services. Send application and vita before July 1 1983 to: Edward Broadhead. Chairman. Dean of Learning Re- 
sources Center Search \& Screen Committee. Pueblo Community College 900 W. Orman Avenue, Pueblo, CO 81004 Pueblo Com. munity College is an affirmative action and equal opportunity employer.

GENERAL REFERENCE LIBRARIAN. Position requires an ALA. accredited degree; second subject master' s degree or doctorate desirable; and five years' academic library reference experience with appropriate supervisory experience. Postion carries faculty rank. Responsibilities include administration, planning and supervision of general reference professional staff, services, and collection, in addition to coordinating collection development activities. Rank and sal ary dependent upon qualifications and experience $\$ 16,000-\$ 19,000$. Send letter of application, resume iranscripts and three letters of recommendation to: Office of Academic Alfairs. Librarian Position. Wetherby Administration Bui ding. Western Kentucky University. Bowling Green, KY 42101. Applications will be ac cepted until position is tilled. An attirmative action, equal opportunity employer.

HEAD, GENERAL REFERENCE, Robert W. Woodruff Library. Emory University. Allanta. Responsibulities. manage Reference Desupport staff Areas of service include bibliographic instruction, interlibrary loan, microform reading room, and online bibliographic searching. Coordinates reference collection development and participates in development of the general collections. Minimum qualifcations: ALA-accredited degree depth of subject knowledge and fa miliarity with research techniques, preferably in an area of the human ties or thie sccial sciences; 3-5 years of reference experience with a demonstrated competency in supervisory and managerial skills, preferably in a large academic or research library: or equivalent combination of education and experience. Reading knowledge of at least one modern European language. Demonstrated strong communication and public relations skills required. Salary and rank dependent upon qualifications and experience (minimum rank and salary Librarian II, $\$ 20,000$ ). Send letter, resume, and names of three references, by July 15, 1983, to: Nancy A Books, Director of Public Services, Robert W Woodruft Library Emory University, Atlanta, GA 30322. An affirmative action equal opportunity employer.

HEAD OF SERIALS CATALOGING. Catalog serials originaily for inpul into OCLC-CONSER or upgrade shared records with CONSER authorization Represent UF at CONSER operational meetings at OCLC Coordinate along with the Department Chairman other de partments and satellte libraries serials developmenton the Library's new in-house automated system developed from Northwestern Uni- versity software. Train beginning professionals in serials cataloging. MLS irom ALA.accredited school required. Feading knowledge of at least one modern European language preferred. Salary range for Assistant Librarian: \$13,030-\$21,700; Associate Librarlan. (5 years of profess onal experience) $\$ 15,660-\$ 26,100$. Florida State Retirement, faculty status, Elue Cioss/B Le Shieid group plan, 22 days vacation Send letter of application with complete resume with names of five references and salary requirements by July 1 , 1983, to James $\mathrm{H}$. Renz Associate Director for Technical Services, 216 Library West, University of Florida, Gainesville, FL 32611 . EEO/AAE

HEAD OF SPECIAL COLLECTIONS. Oversees the operations and actively pursues the continued development and expansion of the Libraries' Special Collections, Participates in public relations, fund raising. special events, and grant proposals related to the Collections. Fequires ALA-accredited MLS or minimum of 5 years exper ence in book trade, archives or special collections administration Graduate degree in American literature or history strongly preferred Salary mid-20's depending on qualifications. Excellent benefits in cluding choice of retirement programs. The University of HoustonCentral Campus Libraries has 1.4 million volumes a malerials budget of $\$ 1.9$ million, and a staff of 54 professionals and 170 support statt. Applications accepted thru July 1, 1983. Send letter of application, names of 3 references, and resume to: Dana Fooks, Unversity of Houston Libraries, 4800 Calhoun, Houston, TX 77004 Equal opportunity employer

HEAD, OPTOMETRY LIBRARY. Assistant or Associate Librarian (one-half FTE position). Responsible for administering the library. Also responsible for the provision of reference services and library instruction; the establishment of library policies and procedures of the University Libraries; the selection training, and supervision of $i$ brary statt; the maintenance of bibliographic control of the collection in cooperation with Technical Services: and the preparation of budget requests. Serves as the fund manager in the selection of materials to support the curriculum and research activities of the School of Optometry and the Department of Psycho ogica Optics. Master's degree from an ALA-accredired library schcol; minimum of 2 years post-MLS library experience; demonstratec ability to supervse ability to relate effectively to faculty, students, and staff, some acadernic background in science or experience in science-oriented library is preferable. Ability to communicate effectively both oraliy and in writ ing Ability to meet the responsibilities and requirements of a tenure rack appointment Salary dependent on qualifications and experence Salary floors will be observed: Assistant \$15,800; Associate. $\$ 18.500$ Send lenters of application to Anne Rimmer PersonnelOificer, Indiana University Libraries, Bloomington. IN 47405 (812)

\section{COLUMBIA UNIVERSITY LIBRARIES}

\section{Head of Serials Acquisitions}

Under the general direction of the Chief of the Support Division, this position has responsibility for adminIstering a centralized serials function for the Columbia Library System. The position has direct responsibility for 16 full-time staff members; coordinating routines and work flow; planning and implementing change in an evolving technological environment; establishing priorities; resolving problems relating to the ordering. receipt, and payment of serial materials; and developing a thorough knowledge of publishing and sources of supply.

In addition to an accredited MLS, qualifications are administrative ability as demonstrated by successful relevant supervisory experience; a substantial knowledge of serials; the ability to work with staff in other library units and outside vendors; effective writing and speaking skils; evidence of professional creativity and initiatıve; familiarity with computer-assisted technical processing in a large research library; and the ability to work with a broad range of languages, with preferential consideration being given to applicants with a working knowledge of French or German. Preferential consideration will also be given to applicants with relevant acquisitions and/or bibliographic experience.

Submit resume, including salary requirements and three references, to:

\section{Box 35, Butler Library \\ Columbia University \\ $535 \mathrm{~W}$. 114th Street \\ New York, NY 10027}

\section{Salary ranges for 1982-83: Librarian II, \$22,500-\$29,250: Librarian III \$25,500-\$36,975. Deadline for applications: July 31, 1983.}


335-3403. Closing date for applications: no earlier than June 15 , 1983. Indiana University is an equal opportunity, affirmative action employer

INSTRUCTION AND ORIENTATION LIBAARIAN, AsSIstant or Associate rank Responsibililies: planning developing and coord. Assoclate rank Responsibililes: planning. developing, and coord. nating instruction and orientation for the Main Library and the Branch direction and assislance to other librarlans who participate in in structional activities, and collecting, creating, and maıntaining files of instructional materials Also responsible for publications and other instructional materials. Also responsible for publications and other handouts used in the instruction program. Evaluates the effectivetatt and the university community informed of developments in the libraries' user educalion program Serves as a member of the Public Services Committee's Publications Subcommittee and is invited to meetings of the Public Services Committee Will work 10 hours each week in the provision of reference serv ces in the Undergraduate Li. brary inc uding somenght and weekend hours. Qualificalions. MIS from an ALA-accredited library school; minimum of 2 years of postMLS public service library experience with experience in library insiruction. Demonstrated ability lo plan and coordinate library programs, Ability to work well independently and with others. Familiarity with trends and techniques of library instruction. Verba and written communication skills. Supervisory and reference experience preferred. Ablity to meet the responsibilities and requirements of a tenure track appoiniment Salary dependent on qualifications and experience Salary toors are observed Assistant, \$15,800: Associate $\$ 18,500$ Send letters of application to: Anne Rimmer. Personnel Officer, Indiana University Libraries. Bloomington, IN 47405; (812) 335-3403. Closing date for applications: no earlier than June 15 . 1983. Indiana University is an equal opportunity, affirmative action emplayer

INTERNATIONAL DOCUMENTS LIERAAIAN. The pOsition re porting to the Head of Dccuments combines reference and iechnical responsibilitues for US UN and other International documents, and is specifically charged with planning and supervising collection de. velopment and technical work for several international colliections. Participates in library instruction, faculty outreach and ontine refer ence searching. Supervises one part-tıme assistant. Required: MLS from an ALA. accredited library school interest in government publcatıons strong public servce orientation. Preferred: experience witf government publications, familiarity with onlıne searching tech niques; subject master's in a social science field; proficiency in Western European language, familiarity with cataloging rules. Entry level position. Rank of Attiliale Librarian. Salary, \$14,000. Paid health insurance and retirement. 25 days vacation. Additional benefits. Send resume and either names of three references or a piacement address 10. Winn Margetts, Library Personnel, Universily of Utan Li braries Salt Lake Ciry, UT 84112. Interviewing at ALA In Los Angeles. Deadline June 30 1983. Equal opportunity, attirmative action employer

LIBRARIAN, ARCHITECTUAE \& FINE ARTS LIERARY AND MUSIC LIBRARY. The University of Florida Libraries is looking for a librarian to administer the operations of the Architecture \& Fine Arts Library and the Music Library. Applicants should have an MLS from an accredited Ibrary school, at leas! six years pertinent protessiona experience, and demonstrated ability to supervise and to work effectively with faculty, staft and siudents. The appointment is for twelve months with faculty status and tenure track. There are twenty-two working cays vacation per year, eight paid holidays, and state retırement plan at no cost to the employee Appointment will be at the Associate University Librar an rank with a salary belween $\$ 15,660-\$ 25,100$. Applications should be made by July 31, 1983 10: R. Max Willocks, 215 Library West, University of Florida Libraries. Gainesville, FL 32611 . The University of Florida Libraries comply with Section 503 of the Rehabulitalion Act of 1973, and is an equal opportunity alfirmalive action employer.

ORIGINAL MATERIALS CATALOGER. Tririty University of San Antonio Texas, invites applications for the position of Original Materials Cata oger, a facully appointment in a rapidly-growing and dynamic university library. Trinity is strongly committed to excellence in support of the liberai arts tradition at the bache or s and master's de gree levels. Primary responsiblities include cataloging: all English language monographic mater als requiring origuna cataloger; some tore gn language monographs and all Trinity theses and research projects. May have some responsibility for the daily operations of

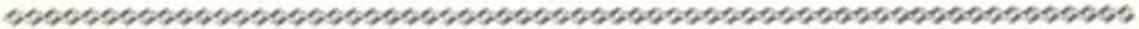

\section{UNIVERSITY OF WISCONSIN}

\section{Associate Director for Collection Development}

The University of Wisconsin General Library System is accepting applications for the position of Associate Director for Collection Development. Benefits include 22 vacation days, sick leave, group health and life insurance and a state retirement plan. Salary minımum: $\$ 40,000$

The Associate Director for Collection Development of the University of Wisconsin-Madison libraries has primary responsibility for collection development policies and procedures for the General Library System and for the allocation of its acquistions budget (currently about 2.5 million dollars). In coordinating collection policies, priorities, and procedures, the Associate Director for Collection Development considers the advice of the selectors (who include the subject bibliographers and the Branch Librarians), the Library Coordinating Council, the University Library Committee, faculty, and administrators. The Associate Director for Collection Development maintains close contact with campus-wide academic planning activities in order to relate library collection development policy to the wider planning process on the Madison campus. On matters of collection development and administration, the subject bibliographers and the Curator of Rare Books report to the Associate Director for Collection Development; the Branch Librarians report to him or her on matters of collection development alone. In addition, the Associate Director for Collection Development is responsible in the area of collection development for preparing grant proposals and initiating other fund-raising activites. The Associate Director for Collection Development reports to the Director of Libraries and works closely with the Director in the overall administration of the General Library. In certain circumstances he or she serves as Acting Director in the absence of the Director. The Director of Libraries may delegate to the Associate Director for Collection Development the function of liaison with the University of Wisconsin System and other State libraries and regional networks in the area of collection development.

The candidate must have an MLS from an ALA-accredited library school and a strong academic back ground, and must show evidence of substantial scholarly achievement, broad bibliographical knowledge and five years of relevant experience in a major research library. Applications including resume, and the names, addresses and telephone numbers of three references should be directed to: Sandra Pfahler, Assistant Director for Budget and Personnel, 360 Memorial Library, 728 State Street, Madison, WI 53706. Applications must be postmarked by June 30, 1983. 
OCLC including supervision and traning of OCLC operators Fe quired qualifications include: the MLS from an ALA-accredited Ibrary school; knowledge of AACR2; knowledge of Library of Corgress classification system and subject headings; reading knowledge of at least one foreign language knowledge of the OCLC system; and intliative creativity, and strong communications skills Highly desirable is cataloging experience in an academic library. An additicnal graduate degree is also desirable Instructor or Assistan Professor rank with tenure-track. Salary minimum of $\$ 16,500$ higher depending on experience or other qualifications. Twelve month ap pointment. TIAAVCREF and liberal ringe benefits. Send lettes of app|cation, delaled resume and names of three references by July 7 . 1983, to: Chair, Search Committee. Origınal Materıals Cataloger Trinity University Library. 715 Stadium Drive, San Anionio, TX 78284. Affirmative action, equal opportunity employer.

PROgRAM MANAGER. The Research Libraries Group (ALG) io cated on the Stantord Campus is a consortium owned by twenty five of the nation's major universities and other research Institutions. RLG is committed to the development of innovative applications of com puter technology to the capture, storage, retrieval and delivery of informalion to support research and scholarshipin the U.S. RLG is currently recruiting two Program Managers to support the daly operation of the Shared Resources, Collection Development and Preservation Programs of the corporation. Responsibilities will include: analysis of collection development verification studies; management of Conspectus data colection and producis; analysis of interlibrary loan statistical data: management of RLG's reference liaison program; management of activities associated with the preservation projects: and grants admınisiration staff support. Qualifications: MLS cegree or equivalent three years experience as a refer ence librarian bibliographer curator or cataloger in a major research library: strong organizalıonal, editoral, verbal, writing and interpersonal skills Reading knowledge of one or more foreign lanugages statistical skills. supervisory experience, and familiarity with RI IN desirable. Salary: $\$ 1,854-\$ 2,312 / m o n t h$. To apply, submit resume with the names of 3 references, to the following address. For further iniormation contact: Art Wilson Stanford University Old Pa. vilion (Personne), Stanford, CA 94305; (415) 497-3117. Equal op portunity employer through affirmative action.

PUBLIC SERVICES LIBRARIAN to develop and coordinate an or Ine information retrieval system. Must have library degree from an ALA-accredited library school. Must be able to communicate and work effectively with all segments of the academ c community. Expe rence in database searching highly desirable. Will participale in ger eral reference services, including library insiruction. Twelve month apoointment with faculty rank. Salary range $\$ 17,000-\$ 22,500 \mathrm{de}$ pendent upon experience and qualifications. McNeese State Unversity has a library budget of $\$ 1.059$ million and over 260,000 vo umes. 13 professiona. librarians serve a faculty of 305 and sluden population of 7,500. Interviews can be arranged at ALA In Los Argeles. Send letter of application, names of 3 references, and current cesume before July 1, 1983 10: Richard H. Reid. Direcior of Library Services. Frazar Memorla Library. McNeese Siate University, Lake Charles. LA 70609 . An equal opportunity employer

AEFERENCE LIBRAAIAN, EDUCATION LIBRAFY. Aftliate or AS sistant Librar.an. Responsible for the provision of reference services. including computer-assisted reference services and library instruc tion and orientation; coorcinating the activities of the reference assis ant and the preparation of bibliographies and other documents Some night and weekend hours are required MLS from an ALA accredited library school: background in education andior iniormaton science; minimum of cne year post-MLS public services experence preferred. Experience with computer-assisted reference services: basic knowledge of education reterence materials. demonstrated ability to relate effectively to students, faculty and stat ability to commuricate effectively both orally and in wriling. An edu cation degree and/or relevant experience and supervisory exper ence are preferred. Abilty to meet the responsibilities and require ments of a tenure-track appointment. Salary dependent on qualifications and experience. Salary floors are observed: Afiliate $\$ 14,500$; and Assistant, $\$ 15,800$ Send letters of applicalion to. Anne Gimmer. Personnel Officer, Indiana Universily Lubraries. Bloamington. IN 47405: (812) 335-3403. Closing date for applica tons: no earlier than June 15, 1983 . Indiana University is an equa opportunity, affirmative action employer.

AEFERENCE LIGAAAIAN. Two positions available as subject spe cralist in busıness assigned to the Graduate Business Admiristration Library. Principal duties. relerence assistance, database searching. orientation, and participalıon in classroom instruction. Oualifications accredited $M L S$, degree in business or related subject area preter red. Two years experience in an academic or special business brary. Benelils. faculty status (subject master's degree required for promotion beyond the rank of Library Associate, Instructor equiva lent): TIAACAEF: five weeks annual vacation. Salary: minimum $\$ 20.000$ Apply: send resume and letter of application, including the names addresses and telephone numbers of three references by June 30, 1983 to: New York University, Elmer Holmes Bobst L. brary, 70 Washınglon Square South, New York, NY 10012. Attn Connie Colter. NYU is an affirmative action instilution.
REFERENCE LIRAARIAN, UNDERGRADUATE LIBRARY, Re sponsible for providing reference services, teaching in library in struction program, and participating in collection development. ALA-accredited MLS, or equivalent, required, reference expenence preterred: library instruction and calabase searching experience de sirable ability to relate well with undergraduate students; effeclive communication skills. Tenure-track position. 12-month appointment 24 days annual leave, tuition remission, usual benefits Salary ranges, dependent upon qualifications: Instructor $\$ 14,000-\$ 16,000$; Assistant Prolessor, $\$ 16,000-\$ 18,000$. Send let ter of application resume and 3 lenters of reference or placement folder by July 15 to: Jill Keally. Personnel Librarian. The Universily of Tennessee Library, Knoxville, TN 37996-1000. UTK is an EEO, afffirmative action, Title IX, Section 504 employer

REFEAENCE LIEAARIAN/VISUAL AATS SPECIALIST, Genera reference, online searching and bibliographic instruction in library of college with special programs in the periormıng and visual arls. Colection development in visual arts and art history; responsibulity for slide collection and picture file. Master's degree from ALA. accredited library school and knowledge of French, German or Ital. lan required preference given to candidates with second masier sin art history. Salary: $\$ 15,500+$ depending upon qualificat ons and ex. perience. Faculty status and liberal tringe benefits including TIAA /CREF. Send resume and names of 3 references by $J$ une 30, 1983 to: Deanne Molınari, Alfirmative Aclion Officer, SUNY College at Purchase. Purchase, NY 10577

SCIENCE REFERENCE LIGRAAIAN/BIELIOGRAPHEA. Re sponsible for the Library's collection development in assigned SCence discip ines, including approval plans, firm orders, gifts and seri. als. Provides service at the Reference Desk, including some weekend and evening hours. Panicipales in an active program of brary instruction and computerized dalabase searching in the disc plines of selection responsibulity. Requires a master s degree from an Al A-accredited library school and an undergraduate degree in science discipline or professional library experience in science reference, Salary $\$ 15,500-\$ 19,500$ depending on qualifications. Exce lent berefits including choice of retrement programs The University of Houston-Central Campus Libraries has 14 million volumes. a ma terlas budget of $\$ 1.9$ million, and a statt of 54 professionals and 170 support stat Applications accepted thru July 1, 1983 Send letter of applicafion, names of 3 references, and resume lo Dana Rooks, Universily of Housion Libraries, $4800 \mathrm{Ca}$ houn. Houston. TX 77004 Equal opportunity emptoyer

SCIENCE REFERENCE LIGAARIAN, Paricipates with other librari ans in general reterence dutes, onl ine searching, bibliographic in science departments, College of Engineering. and College of Nurs

g. ALA-accredited master's. Highly desirable: two years reference and bibliograpnic instruction experience in an academic library; ex perience in online searching. particularly in the sciences: undergrad. uate and/or advanced degree in science. Twelve-month appoint ment; proposed efleclive date. September 1983 faculty rank and salary commensurate with qualificalions, \$16,500 minimum, TIAA. ICREF and university mandated benefits. Send resume and names of three references by July 15, 1983, to: Raymond A Frank e. Direc ror, J. Murrey Atkıns Library. The University of North Caroina a Sharlotte is an equal opporlunity attirmative action employer Wohen and minorities are encouraged to apply

SEAIALS CATALOGEA, Trinity Un versity of San Antonio, Texas inviles applications for the position of Serials Cataloger, a faculty ap pointment in a rapidly-growing and dynamic universily library Trınity s strongly committed to excellence in support of the liberal arts trad ion at the bachelor's and master's degree levels Frimary respons bulities include cataloging of all serials tilles, cataioging monographs in one forelgn language. elther French. Russian, or German; and cal aloging all non-book materlals. May nave some responsibility for the daly operation of OCLC Including supervision and training of OCLC operators. Aequired qualifications include the MLS from an ALA. accredited library school knowledge of AACR2, particularly as re lated 10 serials: knowledge of Library of Concress classification sys. tems anc subject headings; reading knowledge of at leasl one of the foreign ianguages specified above; familiarity with OCL C or other in house automaled systems; and initiative, creativity, and strong communications skils. High y desirable is experience in serials accuis. tions or serials cataloging in an academic library. An additiona graduate degree is also desirable. Instruclor or Assistant Professor rank with tenure-track. Salary minimum o' \$16,500, highes depend ng on experience or other qualificalions. Twelve month appoint ment. TIAANCREF and liberal fringe benefits. Send leiter of applicathon detalled resume and names of three references by July 7,1983 to Chair Search Committee. Serıals Cataloger, Trintty University L. brary. 715 Stadium Drive. San Antonio, TX 78284 . Attirmalive action equal opportunity employer

SERIALS CATALOGING SECTION HEAD, UniversIty of California. Santa Barbara. Supervises serials section of Cataloging Department. Duties include original cataloging and classification of serials and analytics, revision of conlributed cataloging work by library as sistants, and resolution of complex bibliographical problems. Re 
quirements: $M L S$, at least two years professional experience in serials cataloging, experience with AACR1 and AACR2, LC classification and LC subject headings, online cataloging systems, and supervisory experience. Facility with European languages and with aulomaled seriais cataloging desired Salary range: $\$ 17,412-\$ 30,648$ dependent upon experience and qualifications $\$ 17,412-\$ 30,648$ dependent upon experience and qualifications
Applications must be received by July 15,1983 . Send letter of application. names of references, and resume to: Margaret Deacon, Assistant University Librarian, UCSB Library, University of California Santa Barbara, CA 93106. An equal opportunity, affirmative action employer

STAFF SERVICES LIBAARIAN, University of Georgia (salary minjmum \$17.000). Duties: responsible for administering classified staff personnel program, establishing orientation and staft development programs, developing and maintaining a comprehensive personnel manual, and assisting with personnel funclions reiated to librarians. Reports to the Assistant Director for Administrative Services. The L braries staff consists of 150 classified personnel, 65 librarians, and 200 student assistants. Qualificalions' ALA-accredited MLS; knowledce of and demonstrated interest in academic/research librarianship; ability to work effectively with all levels of library staft and with other university personnel: interest in and ability to present effective orientation and staff development programs; ability to handle personnel matters with sensitivity and confidentiality: commitment to af firmative action guidelines; excellent commurication skills; effective organizational skils; knowledge of principles of personnel manage- ment preferred Application procedure. send letter of application by July 8, 1983, including resume and names of three references to: Bonnie Jackson Clemens, Assistant Director for Administrative Se vices, University of Georgia Libraries, Athens, GA 30602. This position will be filled only if suitable applicants are found. An equal opportunity, affirmative action instilution

USER EDUCATION LIBAARIAN. 75\% position (30 hrs/week) there is some possibility that the position may become full-time. Assists in planning, implementing and evaluating user education programs for undergraduate and graduate students: includes classroom instruction. Contributes to the development of instruclional materials, and provides some reference service Requires llexible scheduling to meet changing program needs. Reports to the Director of Library User Education. Faculty are expected to meet University recuirements for tenure and promotion, including research, publication, and service. Required: MLS from ALA-accredited program demonstrated interest in bibliographic instruction; abilily to commu nicate clearly and effectively, orally and in writing. Desirable: experience in library user education, with instructional use of audio-visua materials and with online bibliographic systems broad subject background. Salary: $\$ 12,000-\$ 14,400$ for $75 \%$. Apply by 8 July to Sharon A. Sullivan, Personnel Librarian, Ohio Stale University Li brarles, 1858 Nell Avenue, Columbus, $\mathrm{OH} 43210$. Submit detaled resume with names and addresses of at least 3 references. An EFO/affirmative action employer. Oualified women, minority and handicapped persons as well as others are encouraged to apply.

ASSISTANT DIRECTOR FOR TECHNICAL SERVICES. POsition available: 1mmediately. Requirements: requires minimum of an ALA-accredited master's degree in library science and five years of progressively more responsible professional experience in the technical services of a large academic 1ibrary. A second master's preferred. Demonstrated successful supervisory experience and thorough knowledge of automated systems. Demonstrated ability to commicate effectively with various levels of university staff and to manage a large acquisitions budget. Duties and responsibilities: particlpation in overall library planning, budget preparation and the formulation of library policies; development and implementation of plans and policies for Technical Services in consulation with divisional staff; coordination of automated processes in the division; preparation of annual and special reports on problems and progress in Technical Services; representation of the department on the Library Council; assumption of any special responsibilities and duties that are assigned by the library administration; directly supervising eight departuent and unit heads; coordination of divisional staff training and development. Benefits: excellent benefits package including health, dental, life and disability insurance; tax-deferred annuity program available; educational assistance program. Library Information: the University of Missouri-Columbia Library, an ARL library, serves a student body of 24,500 and a faculty of 2,600 with a collection of over two million volumes and over 2.4 million microforms. An online catalog, to serve the four campuses of the University, is being developed. General information: founded in 1839 as the first state university west of Mississippi, the University of Missouri now has four campuses. The Columbia campus has 19 schools and colleges, and is located midway between Kansas City and St. Louis. Application deadline: July 15, 1983. Minimum salary: $\$ 33,500$. Send letter of application, names of three references and resume to: Pat Burbridge, Personnel Coordinator, 104 El1is Library, University of Missouri-Columbia, Columbia, MO 65201. An equal opportunity employer.

BUSINESS LIBRARIAN. Primarily a public service position. Works closely with head to determine activities, policies, and procedures. Shares reference and other responsibilities, such as coordination of library instruction, database searching, computerized circulation activities, preparation of reference guides, hiring and scheduling of student staff. A staff of three library assistants plus students complement the three professional positions. Required: ALA-MLS; degree in business; library public service experience with emphasis on reference; sorae knowledge or experience with online database searching. Instructor rank, faculty status. \$14,500 for 12 months, two-year 
appointment ending June 30, 1985. May be renewed. Twenty days annual leave plus ten paid holidays. Excellent fringes. Send letter of application, resume, academic credentials, and placement file to: Carl Sachtleben, Director of Libraries, Western Michigan Unfversity, Kalamazoo, MI 49008. An EEO, AA employer.

CATALOG MAINTENANCE LIBRARIAN, Automated Processing Department. Supervises operation of the section. Responsible for maintenance of the online catalog (LCS) and the card catalog. Selects, trains, supervises, and revises the work of 12 support staff and 10-15 student assistants. Oversees the interface of OCLC data with the online catalog and the matntenance of headings and holdings files. Recatalogs and upgrades catalog information and resolves problems. Is responsible for the operation of the department one or two evenings a week. Reports to the Head of the department. Required: master's degree from ALA-accredited program; at least two years post-MLS experience in original cataloging using AACR2 and LC classsification and subject headings; substantial experience with OCLC or other bibliographic utilities; supervisory experience; ability to communicate effectively orally and in writing; ability to adapt to frequently changing environment. Highly desirable: reading knowledge of one or more Western European languages and familiarity with automated library systems. Faculty are expected to meet University requirements for promotion and tenure including research, publication, and service. $\$ 17,040-\$ 19,560$. Apply by 8 July to: Sharon A. Sullivan, Personnel Librarian, Ohio State University Libraries, 1858 Neil Ave. Ma11, Columbus, OH 43210. Submit resume with names, addresses, and telephone numbers of at least three references. An AA/EEO employer. Qualified women, minority, and handicapped persons, as well as others, are encouraged to apply.

COLLECTION MANAGEMENT DEPARTMENT HEAD. Associate Librarian, $\$ 25,440-\$ 30,672$ for 12 months (ten month option with proportionate salary reduction available). Required: ALA-accredited degree; 7-8 years professional library experience; minimum three years as a collection management librarian in academic library. Send inquiry and resume including names and addresses of three references who have observed candidate's professional performance and human relationships, to: Walter $H$. Roeder, Chair, Search Committee, c/o Library Office, 15-102 California State Polytechnic University, $3801 \mathrm{~W}$. Temple Ave., Pomona, CA 91768. Closing date: July 15. EE0/AA employer.

COORDINATING CATALOGER, AUTOMATED PROCESSING DEPARTMENT (search extended). Supervises operation of the section responsible for editing and input of cataloging data through OCLC to create records in the local online catalog. Trains, schedules, supervises, and revises the work of 10 support staff and 10-15 student assistants. Upgrades, enhances, and solves problems related to cataloging copy through application of AACR2 and LC classification and subject headings; serves as liaison with Catalog Department for resolution of cataloging problems. Compiles statistics and reports, and maintains procedure manuals. Responsible for operation of the department one or two evenings per week. Reports to the head of the department. Required: master's degree from ALA-accredited program, two or more years post-MLS cataloging experience using AACR2, LC classification and subject headings; substantial experience with OCLC or other bibliographic utilities; supervisory experience; ability to communicate effectively orally and in writing; ability to adapt to frequently changing environment. Desirable: reading knowledge of one or more Western European languages. Faculty are expected to meet University requirements for promotion and tenure, including research, publication and service. Salary: $\$ 17,040-\$ 19,560$. Apply by 8 July to: Sharon A. Sullivan, Personnel Librarian, Ohio State University Libraries, 1858 Neil Avenue Mall, Columbus, $\mathrm{OH}$ 43210. Include resume and names and addresses of at least three 
references. An AA/EEO employer. Qualified women, minority, and handicapped persons, as well as others, are encouraged to apply.

HEAD OF CATALOGING DEPARTMENT. Significant professional opportunity for innovative librarian in university library with full online public cataloging. Responsible for unft of three professional and ten support staff. Position includes responsibility for coordination of bibliographic files throughout the library. Minimum qualifications: an ALA-MLS and at least seven years of relevant professional experience, including 1) demonstrated supervisory and management skills; 2) recent in-depth cataloging and automation related activities; 3) experience with OCLC or other bibliographic utilities or networks. Desirable qualifications include background in authority control, non-print inedia, online catalog development. Salary range is $\$ 25,440-\$ 30,672$; 24 days annual vacation and liberal benefits. Position is Assoclate Librarian rank, tenure-track, 12-month. Send by July 17, 1983, names, addresses, and telephone numbers of three current professional references, and resume with complece record of education, experience, and salary, to: Frederick Ryan, Assistant Library Director for Systems and Technical Services, Meriam Library, California State Universicy, Chico, CA 95929. CSU Chico is located 90 miles north of Sacramento in an attractive northern California setting, and is an affirmative action employer.

HEAD OF CIRCULATION AND INTERLIBRARY LOAN SERVICES. Position avallable: September 1, 1983. Requirements: ALA-accredited master's degree in library science. Minimum of five years professional library experience, at least two of which should be in a large academic library. At least two years experience in circulation activities; experience with automated circulation systems highly desirable. Supervisory experlence, communication skills and strong service orlentation essential. Duties and responsibilities: responsible for the administration of Circulation Services, which includes circulation, reserve collection sevices, Interlibrary loans, shelving, billing, security, and the library annex. Supervision of 13 full-time staff members, and approximately 80 student assistants. Supervision of all automated activities and equipment maintenance in the department. Plans for future circulation needs with library administration, appropriate library staff and University Computer Center. Benefits: excellent benefits package including health, dental, 1ife and disability insurance; tax-deferred annuity program avallable; education assistance program. Library information: the University of Missouri-Columbia Library, an ARL library, serves a student body of 24,500 and a faculty of 2,600 with a collection of over two million volumes and over 2.4 million microforms. An online catalog, to serve the four campuses of the Universtty is being developed. General information: founded in 1839 as the first state university west of Mississippi, the University of Missouri now has four campuses. The columbia campus has 19 schools and colleges, and is located midway between Kansas City and St. Louls. Application deadline: July 15, 1983. Minimum salary: $\$ 19,500$. Send letter of application, names of three references and resume to: Pat Burbridge, Personnel Coordinator, 104 Ellis Library, University of Missouri-Columbia, Columbia, MO 65201. An equal opportunity employer.

HEAD, LEARNING RESOURCES CENTER, Mansfleld Campus. Administers Library and Learning Resources programs and services, including planning, budgeting, staffing and directing the activities of the Learning Resources Center which serves the 3,000 students and 175 faculty of the OSU-Mansfield Campus and the North Central Technical College. Manages technical and public services. Reports to the Associate Dean of the Mansfield Campus and, for coordination purposes, to the Vice President for Academic Affairs of North Central Technical College and to the Head of Undergraduate Libraries in Columbus. 
Required: MLS from ALA-accredited program; substantial post-MLS professional experience, preferably in public services; experience in the development and creation of $\mathrm{A} / \mathrm{V}$ materfals and with $\mathrm{A} / \mathrm{V}$ equipment; user-education or teaching experience; supervisory experience; ability to communicate effectively orally and in writing; and to interpret and promote the Learning Resources Center to the campus community. Highly desirable: administrative and technical services and experience, as well as familiarity with the needs of students in a technical program. Faculty are expected to meet University requirements for pronotion and tenure including research, publication, and service. $\$ 22,080-\$ 27,720$. Apply by 8 July to: Sharon A. Sullivan, Personnel Librarian, Ohio State University Libraries, 1858 Neil Ave. Mall, Columbus, OH 43210. Submit resume with names, addresses, and telephone numbers of at least three references. An AA/EEO employer. Qualified women, minority, and handicapped persons, as well as others, are encouraged to apply.

HEAD OF REFERENCE/INFORMATION SERVICES AND COLLECTION DEVELOPMENT. Administers a department of 16 professionals and 31 support staff responsible for reference service, collection development, user education, computer searching, interlibrary loans, government documents, copy service, and four branch libraries (Architecture, Music, Optometry, and Pharmacy). Under the general direction of the Assistant Director for Public Services and Collection Development, this position is responsible for planning, coordinating, and managing the operations of the department, training and evaluating staff, and for the direct supervision of the Assistant Head of Reference, the coordinators of the department's service programs, and the branch librarians. Current projects include a collection analysis project, fmplementation of a library skills workbook into the English core curriculum, and planning for the impact on reference and branch libraries of an online catalog, circulation, and acquisttion system. Requires ALA-accredited MLS, substantial professional experience (5t years) in a major academic or research librry, proven supervisory capability, substantial experience in reference services, leadership ability with strong interpersonal skills, excellent oral and written communication skills. Desirable qualifications include: experience In other areas of responsibility of reference department, with collection development experience highly desirably. Salary from upper $\$ 20$ s, depending on qualifications and experience. Excellent benefits, including choice of retirement programs, $88 \%$ of Social Security paid for first $\$ 16,500$ of salary. The University of Houston-University Park Libraries have a 1.4 million volume collection, a $1983 / 84$ acquisitions budget of over $\$ 2$ million, and a staff of 54 professionals and 170 support staff. The library is a member of ARL. To ensure consideration applications must be received by July 10, 1983 . Preliminary interviews available at ALA. Send letter of application, names of three references, and resume to: Dana Rooks, University Houston Libraries, 4800 Calhoun, Houston, TX 77004. Equal opportunity employer.

HEAD OF TECHNICAL SERVICES. Responsible for all technical services operations; interacts wth Centralized Serials, Acquisitions, and Cataloging Units in Bloomington; includes some public services responsibilities, including reference. MLS from ALA-accredited library school, reading knowledge of at least one modern European language; ability to supervise staff and deal with complicated procedures; 2-3 years experience required; knowledge of AACR2; must be able to meet the responsibilities of a tenure-track appointment. Assistant Librarian rank, minimum salary $\$ 16,000$. 22 days vacation, Blue Cross-Blue Shield, dental, life, TIAA/CREF. Closing date July 7, 1983. Send letter of application and resume, including names of three references, to: James Mullins, Director, Indiana University at South Bend, PO Box 7111, South Bend, IN 46634. Indiana University is an EEO/AA employer. 
HUMANITIES OR SOCIAL SCIENCES/REFERENCE LIBRARIAN, The University of Texas at San Antonlo Library. Duties include general reference, collection development in area of expertise, online searching, library instruction and some supervisory responsibility. ALA-accredited MLS degree and second master's in one of the humanities or social sciences, tralning in online database searching required. Experience in any of the areas of responstbility highly desirable. Salary: $\$ 15,000$ minimum for 12 months with usual fringe benefits. Send letter of application, resume, and names of three references to: Margaret A. Joseph, Assistant Director for Public Services, The University of Texas at San Antonio Library, San Antonio, TX 78285. UTSA is an equal opportunity, affirmative action employer.

LIBRARIAN. Maine Maritime Academy is seeking a librarian with skills in both reader services and technical services with a strong interest in computer applications. Qualifications: MLS, familiarity with AACR2 and with automation. Academic library experience with working knowledge of OCLC, LC classification, and online bibliographical searching preferred. Interest in maritine field desirable. Salary: $\$ 18,200$. Twelve-month appointment. Available: August 15, 1983. Send letter of application, resume, and three references by June 30, 1983, to: Marjorie Harrison, Librarian, Maine Maritine Academy, Box C-1, Castine, ME 04420.

LIBRARIAN, REFERENCE DIVISION, Maryland Historical Society. MLS, genealogical research experience, general knowledge of Maryland history. Administers collection of books, specialized files. Supervises reference and cataloging activity. Plans for improvement of organization and accessibility of collections, including automated acquisitions and cataloging routines. Minimum: $\$ 12,800$. Generous benefits. Available July 1. Resumes to: William B. Keller, Maryland Historical Society, 201 W. Monument St., Baltimore, MD 21201.

MUSIC CATALOGER. The Unfversity of Arizona is seeking a professional librarian responsible for original cataloging of music scores, recordings, and monographs. Serves as the liaison to the staff of the music collection. Requirements: an ALA-accredited degree; experience in cataloging both scores and recordings according to AACR2; strong background or degree in music; experience with LC classification and LCSH; facility with French and German languages preferred; experience with OCLC or a similar utility destred. Salary range $\$ 16,500-\$ 21,000$. Professional librarians at UA have faculty status but twelve-month continuing appointments, earn 22 days of vacation, and have a standard package of holidays and other benefits. Send letter of application, resume, and names of three referees by July 15 to: $W$. David Laird, University Librarian, University of Arizona Library, Tucson, AZ 85721. The University is an EEO/AA employer.

REFERENCE LIBRARIAN, St. Mary's College of Maryland. The College is a publicly-supported liberal arts college with no religious affiliation, located on the water in the country 70 miles southeast of Washington, DC. Duties: reference desk work, bibliographic instruction, online searching (experience in BRS or DIALOG preferred). We are seeking someone with a strong commitment to public services in general and bibliographic instruction in particular. Schedule includes nights and weekends. Qualifications: MLS from ALA-accredited library school. Prefer. given candidates with some previous professional experience. Salary starting range: $\$ 14,666-\$ 15,520$, depending on background and experience. TLAA/CREF or Maryland State Retirement, 22 days annual leave, Blue Cross-Blue Shield. Applications accepted through July 1 , position available August 1983. Send resume and ask three references to write letters of reference to: John G. Williamson, Director of the Library, St. 
Mary's College of Maryland, St. Mary's City, MD 20686. St. Mary's College is an affirmative action, equal opportunfty employer.

REFERENCE LIBRARIAN, University of California, Irvine. Entry level position at Assistant Librarian rank. Responsibilities: general and subject/spectalized reference service ranging from factual information to indepth research. Reference collection development (selectlon, weeding, and management) in 11 terature and other humanitles. Lialson with faculty and students in subject areas. Active participation in orientation and bibliographic instruction program at the undergraduate and graduate levels. Participation in and contribution to general work of the department. Some night and weekend work required. Qualifications: required--MLS, strong commitment to public service with an emphasis on bibliographic instruction and clear conmitment to the profession, strong verbal and written communication skills, ability to work effectively, independently, and cooperatively with others; desirable--MA in English or American literature, professional experience in public service, training or experience in bibliographic instruction, knowledge of both traditional and machine-assisted reference services in an academic library. Assistant Librarian salary range, $\$ 17,412-\$ 22,284$ per year, depending upon qualiflcations and experience. Benefits in UC equal to approximately $40 \%$ of salary. Applicants need to send letters, resumes, and the names of three references to: Michael J. Macinnes, Library Personnel Office, University of Callfornia-Irvine, Po Box 19557, Irvine, CA 92713; (714) 833-7115. Deadline for applications: July 1, 1983. Applicants should indicate whether they will be avallable for a preliminary Interview at the June ALA Conference. UCI is an affirmative action employer. Women and minorities especially encouraged to apply for this position.

SERIALS CATALOGER. Responsible for cataloging and classification of serials in all subject areas. Required: MLS from ALA-accredited school or equivalent; working knowledge of AACR2, LC classification and LC subject headings. Reading knowledge of Spanish and familiarity with OCLC preferred. Appointment at Librarian I level. Minimurn salary $\$ 16,000$. Liberal benefits. Twelve months academic appointment. Closing date for applications July 15, 1983. Please forward resume and three letters of recommendation to: Kate Maniscalco, Administrative Assistant, Tulane University Libraries, New Orleans, LA 70118. An equal opportunity, affirmative action employer.

SCIENCE/SOCIAL SCIENCE CATALOGER. The University of Arizona is seeking a professional librarian responsible for the original cataloging of monographs in selected subject areas, including geography, geology, statistics, economics, and technology. $U A$ is a large, academic research library. Requirements: an ALA-accredited degree; working knowledge of AACR2; experience with LC classification; experfence with OCLC or a simflar utility; at least one foreign language. Advanced degree in a science or social science field is desirable. Salary range $\$ 16,500-\$ 21,000$. Professional librarians at UA have faculty status but twelve month continuing appointments, earn 22 days of vacation, and have a standard package of holidays and other benefits. Send letter of application, resume, and names of three referees by July 15 to: W. David Laird, University Librarian, University of Arizona Library, Tucson, AZ 85721. The University is an EEO/AA employer. 


\section{Checklist of Selected Gale Reference Books}

\section{Contemporary Authors}

Volume 107 brings the total coverage to over 72,000 writers and media personalities. Cumulative indexes in even numbered new volumes. $\$ 76.00 /$ vol. (SO) CA New Revision Series. Vols. 1-8 in print. $\$ 76.00 /$ vol. (SO)

\section{Contemporary Literary Criticism}

This continuing series provides excerpts from current criticism of major authors now living or deceased since 1960. 150-200 authors per vol. Vols. 1-24 in print. $\$ 76.00 /$ vol. (SO)

\section{Twentieth-Century Literary Criticism}

Each volume furnishes long excerpts from representative criticism on the great novelists, poets, and playwrights of 1900 1960. Author portraits, starting with vol. 4 . A bout 600pp. per vol. Vols. 1-9 in print. $\$ 76.00 /$ vol. (SO)

\section{Nineteenth-Century Literature Criticism}

Meets the need for a convenient source of wide-ranging critical comment on authors of 1800-1900. Each volume presents definitive overviews of about 30 authors. About 600pp. per vol. Vols. 1-3 in print. $\$ 74.00 /$ vol. (SO)

\section{Dictionary of Literary Biography}

A multi-volume series designed to fill a long-standing gap in literary biographical scholarship. Each volume focuses on a specific literary movement or period, so the entire series will ultimately encompass all who have contributed to the greatness of literature in America, England, and elsewhere. Vols. 1-17 in print. (SO) (Write for details)

\section{Contemporary Issues Criticism}

Gathers excerpts from many critics on a wide range of contemporary issues, all fully indexed by writer, critic, and subject. About 60 writers per vol. About 600pp. per vol. Vol. 1 in print. $\$ 66.00 /$ vol. (SO)

\section{Biography Almanac}

2 nd ed. A guide to biographies of over 23,000 newsworthy persons, past and present. Entries include data for quick identifications. Vol. 1. 1,352 pp. 1983. $\$ 48.00$. (SO) Vol. 2, Chronological Index by Year, Chronological Index by Date, Geographic Index. 1,272 pp. 1983.\$48.00. (SO) $\$ 84.00 /$ set. Supplement will cover 2,500 persons. Softbound. 200pp. 1984. $\$ 35.00$. (SO)

\section{Something about the Author}

Heavily illustrated child-oriented reference tool. Each volume contains articles on 150 200 juvenile and young adult authors and illustrators. About 250pp. per vol. Vols. $1-30$ in print. $\$ 52.00 /$ vol. (SO)

\section{Children's Literature Review}

Provides excerpts from current criticism on past and present authors of children's books. About 50 authors per vol. Illustrations, starting with vol. 4 . Vols. $1-4$ in print. $\$ 58.00 /$ vol. (SO)

\section{Magill's Literary Annual}

Each annual two-volume set furnishes critical evaluations and summaries of the previous year's 200 most significant books. About 900pp. per set. Annuals for 19781982 in print. Published by Salem Press. Available in North America from Gale. $\$ 50.00 /$ set. (SO)

(SO) These titles are available at Gale's $5 \%$ Standing Order discount.

All Gale books are sent on 90 -day approval. Deduct $5 \%$ if you send check with order. Customers outside the U.S. and Canada add $10 \%$ to prices shown. 


\section{COLLEGE \& RESEARC.}

LIBRARIES NEWS

\section{Association of College \& Research Libraries}

\section{June 1983}

Vol. 44, No. 6

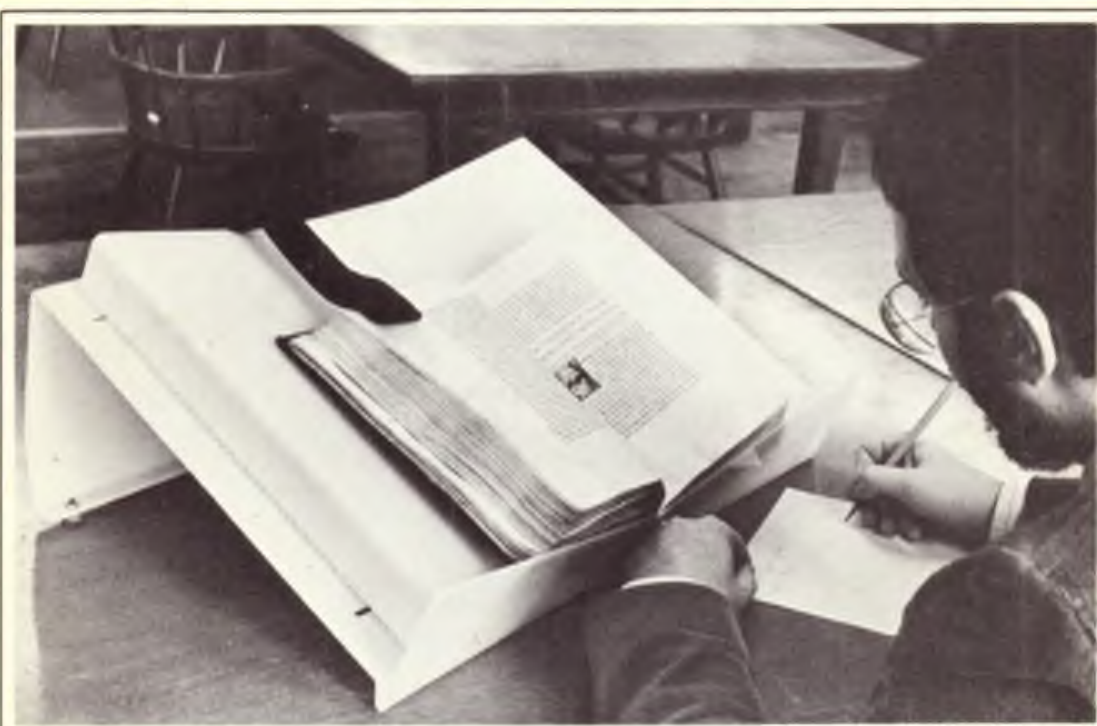

Photos by F. Peter Weil, Newbery Library

Careful handling of rare research materials is a major concern.

Note the cradle, booksnake, and use of pencil.

\section{Special Collections Desk Duty: \\ Preventing Damage}

\section{Anthony J. Amodeo}

Carbondale, Illinois

The desk attendant in a special collections, rare book, or archives reading room is in a unique position regarding the conservation of the collections. Both surveillance for the prevention of theft and monitoring the physical treatment of materials are obviously important responsibilities. An additional contribution which deserves attention is the desk attendant's attitude toward the collections and their handling, which is picked up by both patrons and staff. The following suggestions have been drawn up as a sample of the kinds of concerns that should be addressed in the training of special collections desk attendants. 